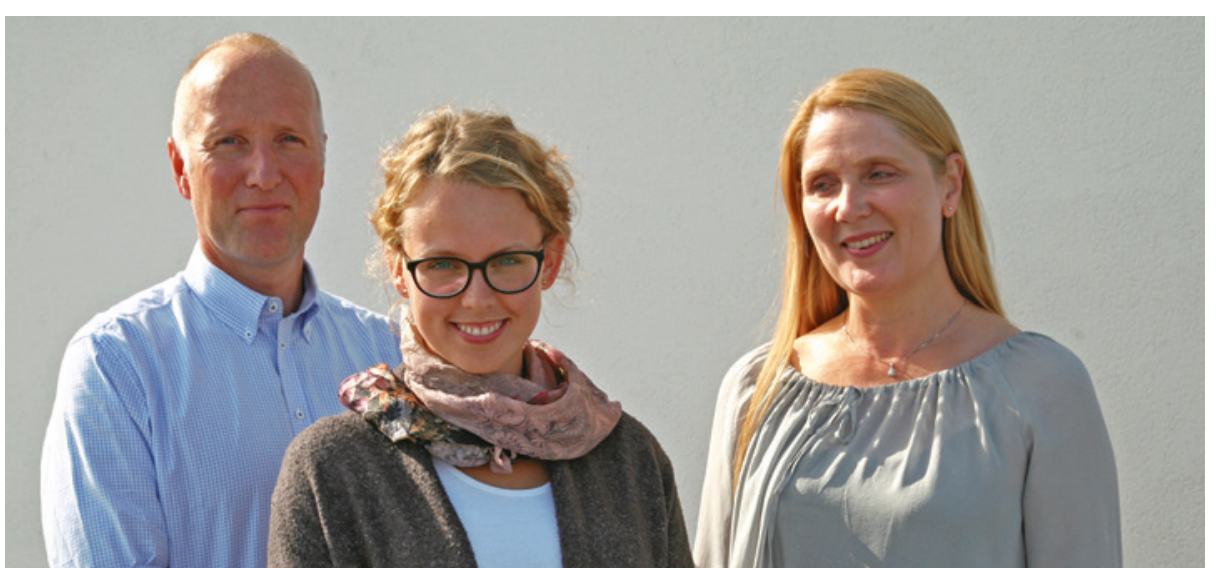

Fra venstre: Jørgen G. Bramness, Ingvild Holdø og Marte Handal. Foto Siri Haugsnes, Folkehelseinstituttet
Ordforklaringer

Alimemazin: Fenotiazin og antihistamin. Midlet ble utviklet i 1950-årene. Kjemisk likner det på antipsykotikumet klorpromazin og antihistaminet prometazin

Medisinsk fødselsregister: Et landsomfattende helseregister over alle fødsler i Norge. Alle fødeinstitusjoner i Norge skal melde fødsler til registeret på et meldeskjema som inneholder navn og fødselsnummer til barnet og foreldrene, opplysninger om morens helse før og under svangerskapet og eventuelle komplikasjoner i svangerskapet eller ved fødselen.

Reseptregisteret: Alle som henter legemidler på resept i Norge registreres i Reseptregisteret. Kjøp av reseptfrie legemidler på apotek eller i dagligvarehandel kommer ikke i registeret.

\title{
Mer sovemedisin til barn av foreldre som selv bruker hypnotika
}

Hvis foreldrene selv bruker hypnotika, får barna deres i større grad enn andre barn utskrevet antihistaminet alimemazin for søvnvansker.

Norske barn får relativt hyppig utskrevet antihistaminet alimemazin (Vallergan) mot søvnvansker. Det er uklart om midlet virkelig har effekt på søvnproblemer hos barn og om det er sikkert å gi til småbarn (1).

Forskere fra Senter for rus- og avhengighetsforskning har gjennomført en farmakoepidemiologisk studie av forskrivning av alimemazin til barn under tre år (2). Studien, som er basert på kobling av data fra Reseptregisteret og Medisinsk fødselsregister, omfattet alle barn født i Norge i 2008 (nesten 60000$)$ og deres foreldre.

$3 \%$ av barna fikk forskrevet alimemazin før de fylte tre år, hyppigst når de var rundt 1,5 år. Flere gutter enn jenter fikk midlet. De fleste fikk bare én resept, men det var en tendens til at guttene fikk flere resepter enn jentene. De som fikk forskrevet alimemazin, fikk også hyppigere antibiotika, antiastmatika og dermatologiske steroidpreparater. Hvis foreldrene selv hadde fått forskrevet hypnotika året før barnet ble født, var det større sannsynlighet for at barnet fikk alimemazin - med oddsratio på henholdsvis 1,7 og 2,9 der mor eller begge foreldrene hadde fått forskrevet slike legemidler.

Det var også en sammenheng mellom forskrivning av alimemazin til barna og forskrivning av antidepressiver til foreldrene.

- Det er viktig å være klar over at forskrivning av alimemazin henger sammen med andre faktorer enn barnets helse, sier studiens førsteforfatter Ingvild Holdø, som er forskerlinjestudent ved Senter for rusog avhengighetsforskning og Universitetet i Oslo.
- Studien viser i tillegg hvordan barns og foreldres helsetilstand henger sammen og må forstås i sammenheng, sier Holdø.

\section{Senter for rus- \\ og avhengighetsforskning}

Artikkelen er skrevet av Ingvild Holdø,

Marte Handal, Svetlana Skurtveit og Jørgen G. Bramness, alle forskere innen farmakoepidemiologi. Ingvild Holdø er medisin- og forskerlinjestudent ved Universitetet i Oslo og en del av forskningsgruppen ved Senter for rus- og avhengighetsforskning (SERAF). Denne artikkelen er hennes første. Professor Jørgen G. Bramness, som er hennes hovedveileder, er instituttleder ved senteret. Han er særlig interessert i forskning på misbruk av reseptbelagte legemidler og på rusutløste psykoser. Professor Svetlana Skurtveit er tilknyttet Folkehelseinstituttet og Senter for rus- og avhengighetsforskning og forsker bl.a. på bruk av reseptbelagte legemidler under svangerskap og hos LAR-pasienter og på bruk av reseptbelagte opioider. Lege og forsker Marte Handal jobber ved Folkehelseinstituttet og forsker på problematisk bruk av reseptbelagte legemidler, spesielt blant barn og gravide.

\section{Hanne Støre Valeur}

hanne.store.valeur@legeforeningen.no

Tidsskriftet

\section{Litteratur}

1. Slørdal L, Bramness JG. Er alimemazin et egnet søvnmiddel for barn? Tidsskr Nor Legeforen 2008 128: $2194-6$.

2. Holdø I, Handal M, Skurtveit S et al. Association between prescribing hypnotics for parents and children in Norway. Arch Dis Child 2013; 98: 732-6.

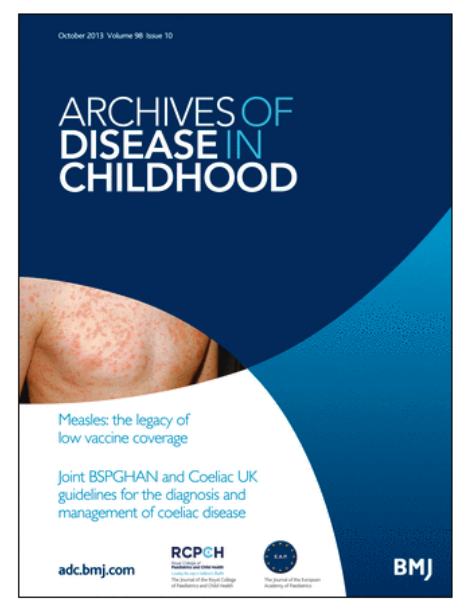

Artikkelen ble e-publisert i tidsskriftet Archives of Disease in Childhood i juli 2013 